University of Wollongong

Research Online

Faculty of Engineering - Papers (Archive)

Faculty of Engineering and Information

Sciences

$1-1-2008$

\title{
Evaluation of undrained response from drained triaxial shear tests: DEM simulations and Experiments
}

Sitharam T G

Indian Institute of Science

Jayan S. Vinod

University of Wollongong, vinod@uow.edu.au

RaviShankar B V

B M S College of Engineering

Follow this and additional works at: https://ro.uow.edu.au/engpapers

Part of the Engineering Commons

https://ro.uow.edu.au/engpapers/4241

\section{Recommended Citation}

T G, Sitharam; Vinod, Jayan S.; and B V, RaviShankar: Evaluation of undrained response from drained triaxial shear tests: DEM simulations and Experiments 2008, 605-608.

https://ro.uow.edu.au/engpapers/4241

Research Online is the open access institutional repository for the University of Wollongong. For further information contact the UOW Library: research-pubs@uow.edu.au 


\title{
Evaluation of undrained response from drained triaxial shear tests: DEM simulations and experiments
}

\author{
T. G. SITHARAM*, J. S. VINOD $\dagger$ and B. V. RAVISHANKAR
}

\author{
KEYWORDS: laboratory tests; numerical modelling; sands; \\ shear strength
}

\section{INTRODUCTION}

The undrained shear response of monotonically loaded isotropically consolidated saturated sands can be characterised by a change in the excess pore pressure generation in the sample. The generation of positive and negative excess pore water pressures is related to contractive and dilative responses. The increase or decrease in pore water pressure continues until it reaches critical state (known as steady state for undrained tests). In general, Casagrande's definition of critical state for sands has been utilised in most commonly used liquefaction analyses, and is referred to as the steadystate procedure (Castro, 1969; Casagrande, 1977; Castro \& Poulos, 1977; Poulos et al., 1985). In the laboratory, consolidated undrained triaxial tests on both reconstituted and undisturbed samples are generally carried out to evaluate the steady state of sands (Poulos et al., 1985). However, it is very clear that steady-state determination from consolidated undrained tests with pore pressure measurements is sensitive to parameters such as initial effective confining pressure and initial fabric (Poulos, 1981; Been \& Jefferies, 1985; Been et al., 1991; Castro et al., 1992). The most recent findings of De Gregorio (1990) indicate that critical state is influenced by the method of soil sample preparation (moist tamping, moist vibration or dry pluviation). This may be due to the volume change tendency caused by the difference in the fabric of the sand, which affects the critical-state response. Furthermore, such behaviour also depends on the loading system equipment's capability to keep up with the potential for sample deformation, an important point with regard to potential differences in testing equipment from one laboratory to another. In this regard, Norris et al. (1997) developed a methodology to predict the undrained shear response of sands from drained triaxial tests carried out from isotropic rebound paths based on the effective stress concept. This method makes it possible for the majority of geotechnical firms to participate in the prediction of static liquefaction and residual strength by performing traditional drained tests with volume change measurements. Furthermore, this method also provides the condition and logic for the development of complete as against limited liquefaction (Norris et al., 1997).

In the laboratory, drained triaxial shear tests were used to predict undrained behaviour using samples consolidated to the desired confining pressure and then rebounded to lower

Manuscript received 21 May 2007; revised manuscript accepted 20 March 2008.

Discussion on this paper closes on 2 March 2009, for further details see p. ii.

* Indian Institute of Science, Bangalore, India.

$\dagger$ University of Wollongong, NSW, Australia.

$\$$ BMS College of Engineering, Bangalore, India. pressures. However, it is seldom possible in the laboratory to consolidate the assemblies along identical paths owing to the difficulty of preparing samples with the same initial fabric.

In this technical note, the method proposed by Norris et al. (1997) is revisited using discrete element methods (DEM) (Cundall \& Strack, 1979), by which means the sample preparation problem can be avoided. In addition, laboratory experiments on clean sands were carried out to validate the numerical simulation results using DEM.

\section{PROGRAMME OF NUMERICAL SIMULATIONS}

Numerical simulations of element tests were carried out using the modified and updated program TRUBAL (University of Waterloo version; Chantawarungal, 1993) on an assembly of 1000 spheres with particle sizes varying from 0.2 to $2 \mathrm{~mm}$ in a periodic cell. A linear force displacement contact model was employed for the numerical simulation program. The linear force displacement law can be expressed in the form

$$
F=k\left(\frac{\delta}{d}\right) d
$$

where $F$ is the normal force, $k$ is the stiffness of the particles, $\delta$ is the distance of the overlap for the two spheres as they approach each other after initial contact and $d$ is the diameter of particles

In general, elastic particles in three-dimensional assemblies can be expected to interact in a non-linear fashion according to a Hertzian relationship between the contact forces and interparticle displacements, given by

$$
F=\frac{E d^{2}}{3\left(1-\mu^{2}\right)}\left(\frac{\delta}{d}\right)^{\frac{3}{2}}
$$

where $E$ is the Young's modulus of the particle, $d$ is the diameter of particle, $\mu$ is Poisson's ratio and $F$ is the Hertzian normal contact force acting between the particles. Particle stiffness can then be evaluated by assuming the same strain $(\delta / d)$ for both the Hertzian and linear contact models. Particle stiffness values determined from the above methodology were kept constant during numerical simulation. Moreover, during the numerical simulations, the critical time step, which is a function of stiffness and mass of the particles, also remains constant. Proper scaling for particle size, density, modulus values and stress values was also adopted to calculate the real input parameters for the element test simulations. The detailed methodology and validation of the stiffness determination can be found elsewhere (Sitharam et al., 2005).

Spheres were generated using a random number generator that places non-overlapping spheres of desired sizes corresponding to the desired grain size distribution at random locations in an initially specified sample size volume. These spherical particles were assigned a shear modulus of $30 \mathrm{GPa}$ 
for the isotropic compression path, a Poisson's ratio of $0 \cdot 3$, a density of $2000 \mathrm{~kg} / \mathrm{m}^{3}$, and a contact friction value of $0 \cdot 5$ for both the isotropic compression and rebound paths. Initially generated assemblies were compressed isotropically by distorting the periodic cell and changing its volume in a strain-controlled loading condition to a confining pressure of $\sigma_{3 \mathrm{c}}^{\prime}=200 \mathrm{kPa}$ and then rebounding to different, lower confining pressures. For generating the isotropic rebound path, a shear modulus of $60 \mathrm{GPa}$ was assigned for the sphere particle, in order to keep $\kappa / \lambda=0.35$ (Lee \& Seed, 1967; Tatsuoka, 1972), instead of $30 \mathrm{GPa}$, as used for the isotropic compression path. During compression the numerical servo control is activated and the sample is compressed and brought to equilibrium under the desired isotropic stress state of $\sigma_{11}=\sigma_{22}=\sigma_{33}$. At the desired stress state, along the isotropic rebound path, the assembly configurations were saved for subsequent drained shear tests. In addition, undrained shear tests (constant volume) were carried out on the assembly isotropically compressed to a confining pressure of $200 \mathrm{kPa}$. The undrained shear tests were simulated by maintaining a constant-volume condition of the sample throughout the triaxial shear tests. Similar constant-volume simulations to capture the undrained behaviour in DEM simulation has been performed by $\mathrm{Ng}$ \& Dobry (1994), Sitharam et al. (2002) and Ashmawy et al. (2003), among others. More details related to the undrained test (constant volume) simulation in DEM, the critical-state behaviour of isotropic assembly and micromechanical data analysis obtained in the DEM simulations have been reported earlier by Sitharam et al. (2002, 2003).

\section{RESULTS AND DISCUSSIONS}

In this investigation, triaxial shear tests were performed, where symmetry in the 2- and 3-directions was maintained at $\sigma_{22}=\sigma_{33}$ : then the stress parameters are represented as

$$
\begin{aligned}
& p=\frac{\sigma_{11}+2 \sigma_{33}}{3} \\
& q=\sigma_{11}-\sigma_{33}
\end{aligned}
$$

In DEM simulations the effective stress tensor is calculated directly from the distribution of contact forces.

\section{Prediction of undrained response: DEM simulations}

Figure 1 presents the variation of volumetric strain with effective confining pressure for a triaxial compression and rebound test. The assembly was isotropically compressed to an effective confining pressure of $200 \mathrm{kPa}$ and then rebounded to different lower effective confining pressures $(180,150,125$ and $100 \mathrm{kPa})$.

Figure 2 shows the plots of various drained shear tests carried out at lower effective confining pressures of 180 , 150,125 and $100 \mathrm{kPa}$. It can be seen from Fig. 2 that there is an increase in peak stress and a decrease in volumetric strain with increase in confining pressure. It will be shown that undrained shear (constant volume) behaviour in a consolidated undrained shear test is the result of opposing volume change tendencies from isotropic and deviatoric stress changes accompanying the change in the effective confining pressures.

The path of undrained stress against strain and effective stress (Figs 3 and 4) of a sample isotropically consolidated to a confining pressure of $\sigma_{3 \mathrm{c}}^{\prime}=200 \mathrm{kPa}$ can be established from drained tests consolidated to the same $\sigma_{3 \mathrm{c}}^{\prime}$. Drained tests were carried out on samples that were isotropically compressed to $\sigma_{3 \mathrm{c}}^{\prime}$ and then rebounded (points 1,2 and 3 in Fig. 1) to different, lower $\sigma_{3}^{\prime}$ values. The resulting curves of

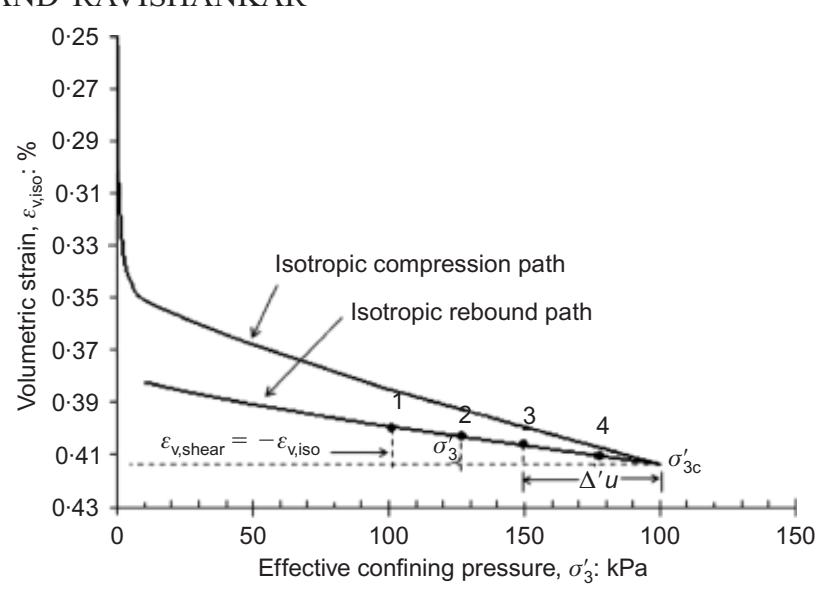

Fig. 1. Isotropic compression and rebound path: DEM simulation results

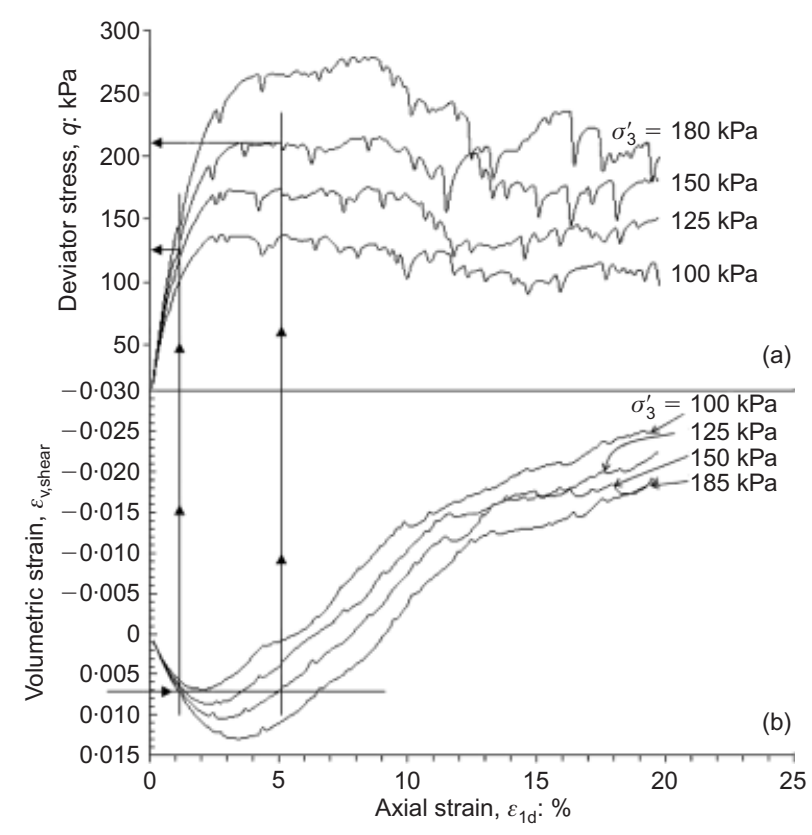

Fig. 2. Drained responses during shear (DEM simulation results): (a) stress against strain; (b) volumetric strain against axial strain

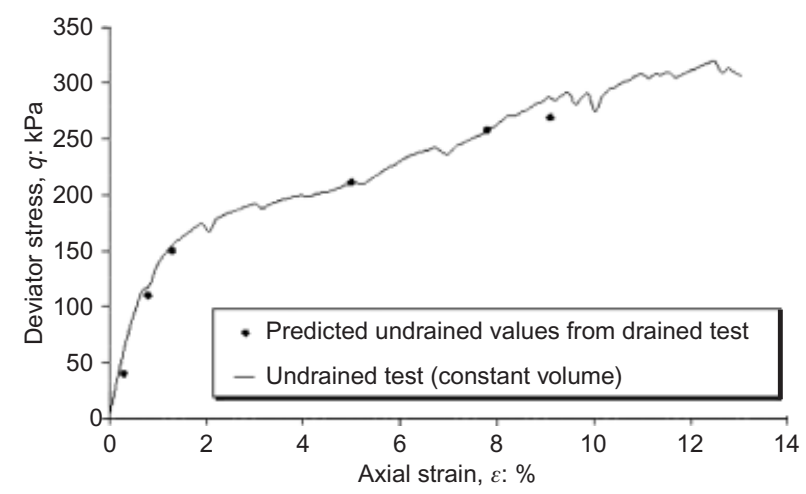

Fig. 3. Undrained stress-strain response: DEM simulation results

drained stress against strain and volume change against axial strain are presented in Fig. 2. These are used with isotropic rebound curves to establish the undrained response (Fig. 3) and effective stress paths (see Fig. 4).

The solid circle points in Fig. 1 (isotropic consolidation and rebounded prior to shear tests) provide the particular values of volumetric strain used to calculate $\varepsilon_{\mathrm{V}, \text { iso }}$ that occur 


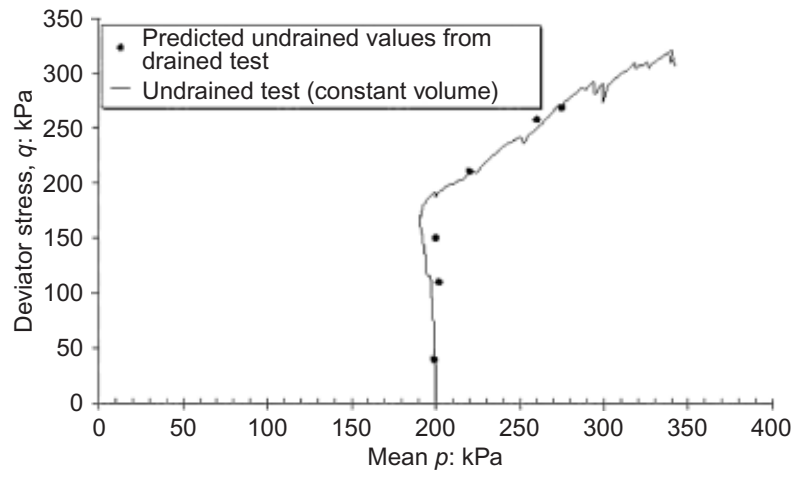

Fig. 4. Undrained effective stress path: DEM simulation results

during undrained loading due to the decrease in the effective confining pressure $\sigma_{3}^{\prime}$. For example $\varepsilon_{\mathrm{V}, \text { iso }}$ due to a drop in confining pressure from 200 to $150 \mathrm{kPa}$ is $0.007(0.413-$ $0 \cdot 406)$ expansion. This is associated with the development of an undrained excess pore water pressure $(\Delta u)$ of $50 \mathrm{kPa}$. Since $\varepsilon_{\mathrm{v}}=\varepsilon_{\mathrm{v} \text {,shear }}+\varepsilon_{\mathrm{v}, \text { iso }}=0$ in undrained shear, then $\varepsilon_{\mathrm{V}, \text { shear }}=-\varepsilon_{\mathrm{V}, \text { iso. }}$. Plotting this value of volumetric strain $(0 \cdot 7 \%)$ in Fig. 2, the $\sigma_{3}^{\prime}=150 \mathrm{kPa}$ volume change curve is intersected at two points. The corresponding values of drained axial strain $\left(\varepsilon_{1 \mathrm{~d}}\right)$ are $5 \%$ and $1 \cdot 1 \%$, with deviator stresses $(q)$ in Fig. 2(a) (for these axial strains) of 213 and $122 \mathrm{kPa}$. The corresponding undrained axial strains $\left(\varepsilon_{1}\right)$ are $4.7(=5-0.7 / 3)$ and $0.86(=1.1-0.7 / 3)$. It is these coordinates of $\left(\varepsilon_{1}, q\right)(4 \cdot 7 \%, 213 \mathrm{kPa}$, and $0 \cdot 86 \%, 124 \mathrm{kPa})$ that appear as two solid circles in Fig. 3. The mean $p^{\prime}$ values corresponding to the predicted undrained deviator stress values have been evaluated from the drained stress path $\left(q / p^{\prime}=3: 1\right)$ carried out on the rebounded samples.

Figures 3 and 4 present the results for the predicted undrained response of the spherical assembly, which has been isotropically compressed to a confining pressure of $200 \mathrm{kPa}$ from drained triaxial tests (solid circles in Figs 3 and 4). In addition, the results of an undrained shear test (constant-volume test) for an assembly of spheres, isotropically compressed to the same confining pressure, is also presented, for comparison (represented by the line in Figs 3 and 4).

An excellent correlation between the undrained shear test result predicted from the drained triaxial tests and the constant-volume shear test results for the assembly is observed. This undrained shear test corresponds to the effective confining pressure $\sigma_{3 \mathrm{c}}^{\prime}=200 \mathrm{kPa}$. In addition, this shows indirectly that constant-volume simulation without the explicit inclusion of pore water pressure in DEM is able to simulate the undrained test results.

\section{Prediction of undrained response: laboratory experiments}

Laboratory experiments were carried out on clean sand samples in order to validate the above numerical simulation results and revisit the method as proposed by Norris et al. (1997) to obtain the undrained shear response from drained shear tests. The sand samples for the present investigation were collected from Ahmedabad, India. The clean sand samples (particle size $>0.075 \mathrm{~mm}$ ) were prepared by removing the silt portion from the sand by washing through a $75 \mu \mathrm{m}$ sieve. The microscopic view of a single sand particle reveals that the particle shape is almost rounded. The index properties of the clean sand samples were found to be: specific gravity $=2.65 ; e_{\max }=0.69 ; e_{\min }=0.44 ;$ medium sand $(\%)=33$, fine sand $(\%)=67$. Triaxial samples $(50 \mathrm{~mm}$ in diameter and $100 \mathrm{~mm}$ high) of initial relative density $25 \%$ were prepared by dry pluviation through a funnel, by raising it along the axis of symmetry of the specimen in the membrane-lined split mould and tapping gently to the volume of the mould to achieve the desired density. The samples were then saturated with de-aired water using back-pressure saturation. All the samples were isotropically consolidated to a confining pressure of $200 \mathrm{kPa}$ prior to shearing.

The undrained stress-strain and effective stress paths of a sample that is isotropically consolidated to a confining pressure of $\sigma_{3 \mathrm{c}}^{\prime}=200 \mathrm{kPa}$ can be established from a drained test consolidated to the same $\sigma_{3 \mathrm{c}}^{\prime}$. Drained tests were carried out on samples that were isotropically compressed to $\sigma_{3 \mathrm{c}}^{\prime}=$ $200 \mathrm{kPa}$ and then isotropically rebounded (points 1, 2, 3 in Fig. 5) to different lower $\sigma_{3}^{\prime}$ values (see Fig. 6). The resulting drained stress-strain and volume change-axial strain curves (Fig. 6) are used with the isotropic rebound curves (Fig. 5) to establish the predicted undrained shear response (see Fig. 7) and effective stress paths (see Fig. 8).

Figures 7 and 8 present the results for deviator stress with axial strain and deviator stress against mean $p^{\prime}$ for an undrained shear test conducted on an isotropically compressed sample at a confining pressure of $200 \mathrm{kPa}$ (represented by solid circles) and superimposed with the predicted

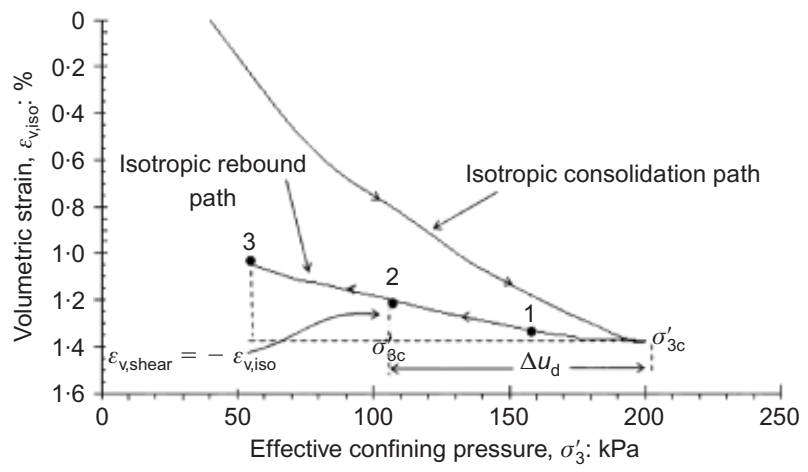

Fig. 5. Isotropic compression and rebound paths: laboratory test results

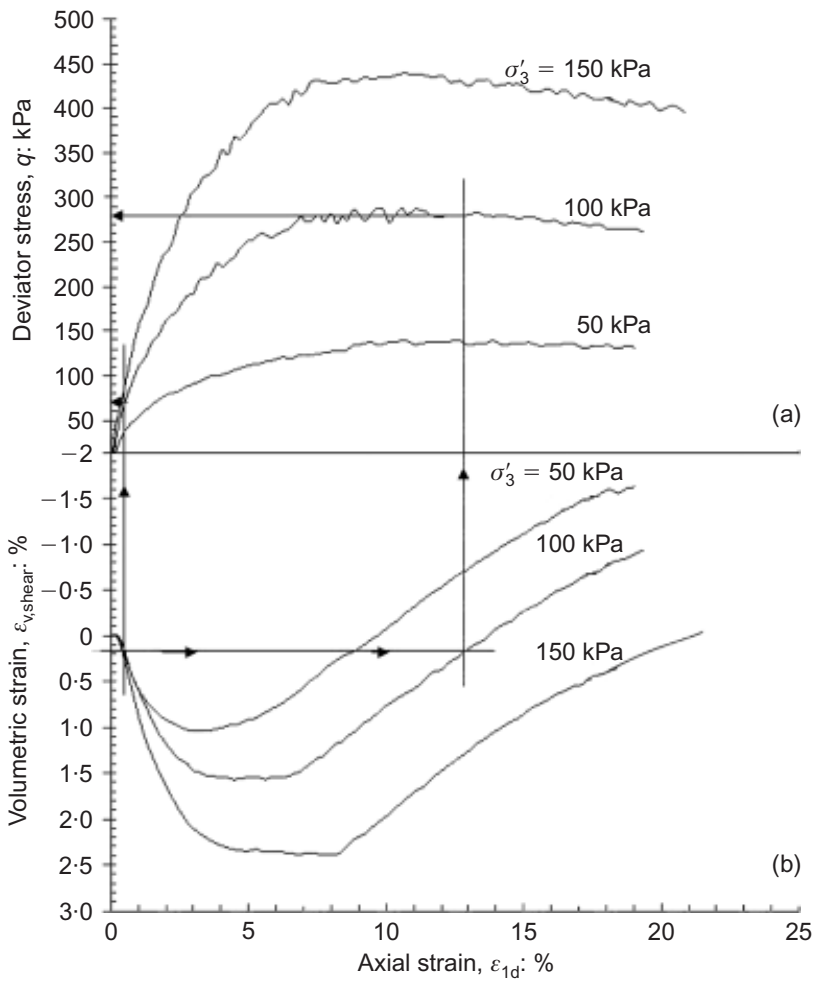

Fig. 6. Drained responses during shear (laboratory test results): (a) stress against strain; (b) volumetric strain against axial strain 
608

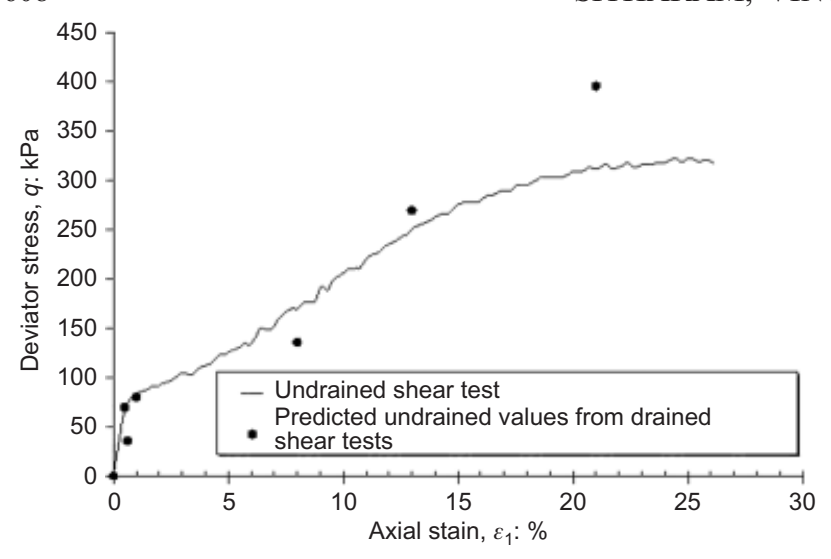

Fig. 7. Undrained stress-strain response: laboratory test results

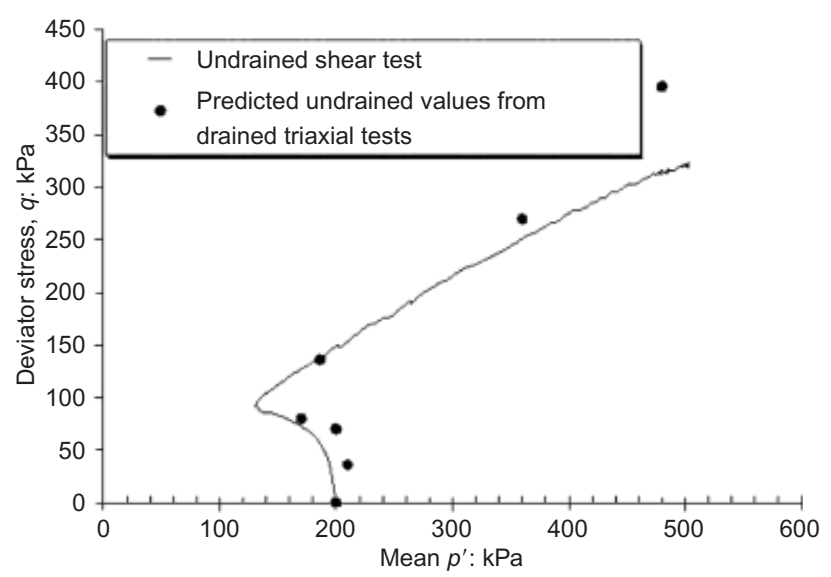

Fig. 8. Undrained effective stress path: laboratory test results

undrained values from drained triaxial tests (represented by the line), as detailed earlier. It is evident from the figure that a good correlation between the predicted undrained values from the drained and undrained shear tests can be observed, with some scatter, which is attributed to difficulties in preparing identical initial samples.

\section{CONCLUSIONS}

A revisit to the methodology proposed by Norris et al. (1997) was presented using DEM. It was observed from the numerical simulations using DEM that an excellent correlation exists between the predicted undrained shear response from drained triaxial simulations and undrained shear (constant volume) simulations. This clearly shows that DEM simulations can simulate undrained shear response realistically, without explicitly incorporating pore water pressures. However, from the laboratory experiments on sand samples, it was observed that there is some scatter in the predicted undrained shear test results from drained triaxial tests, when compared with the undrained shear test results. This may be attributed to the problem of preparing initially identical samples with the same fabric. If the initial identical samples are prepared carefully, it is possible to obtain the complete undrained response from drained triaxial test results without pore water pressure measurements. Thus this should encourage the majority of geotechnical firms with the capability of performing traditional drained tests with volume change measurements to predict the undrained shear response of soils.

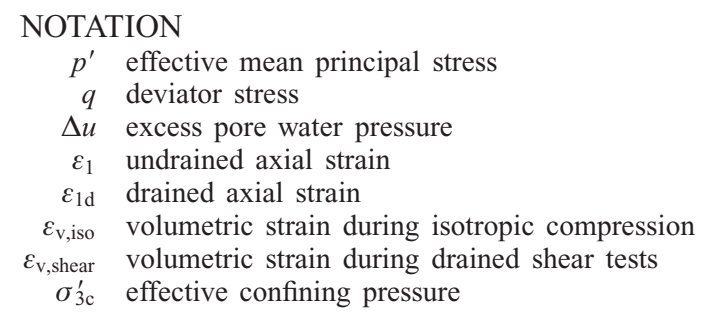

\section{REFERENCES}

Ashmawy, A. K., Sukumaran, B. \& Hoang, V. (2003). Evaluating the influence of particle shape on liquefaction behavior using discrete element modeling. Proc. Ann. Int. Soc. Offshore and Polar Engng Conf., Honolulu, 542-548.

Been, K. \& Jefferies, M. G. (1985). A state parameter for sands. Géotechnique 35, No. 2, 99-112.

Been, K., Jefferies, M. G. \& Hachey, J. E. (1991). The critical state of sands. Géotechnique 41, No. 3, 365-381.

Casagrande, A. (1977). Liquefaction and cyclic deformation of sands: a critical review. Proc. 5th Pan Am. Conf. Soil Mech. Found. Engng, Buenos Aires 5, 79-133.

Castro, G. (1969). Liquefaction of sands. PhD dissertation, Harvard University.

Castro, G. \& Poulos, S. J. (1977). Factors affecting liquefaction and cyclic mobility. J. Geotech. Engng ASCE 103, No. 6, 501-516.

Castro, G., Seed, R. S., Keller, T. O. \& Seed, H. B. (1992). Steady state strength analysis of lower San Fernando Dam slide. $J$. Geotech. Engng ASCE 118, No. 3, 406-427.

Chantawarungal, K. (1993). Numerical simulations of three-dimensional granular assemblies. PhD thesis, University of Waterloo, Ontario, Canada.

Cundall, P. A. \& Strack, O. D. L. (1979). A discrete numerical model for granular assemblies. Géotechnique 29, No. 1, 47-65.

De Gregorio, V. B. (1990). Loading systems, sample preparation and liquefaction. J. Geotech. Engng Div. ASCE 116, No. 5, $805-821$.

Lee, K. L. \& Seed, H. B. (1967). Drained strength characteristics of sand. J. Soil Mech. Found. Div. ASCE 93, No. 6, 117-141.

Ng, T. T. \& Dobry, N. (1994). Numerical simulations of monotonic and cyclic loading of granular soil. Int. J. Numer. Anal. Methods Geomech. 120, No. 2, 388-403.

Norris, G., Siddarthan, R. \& Madhu, R. (1997). Liquefaction and residual strength of sands from drained triaxial tests. J. Geotech. Geoenviron. Engng ASCE 123, No. 3, 220-228.

Poulos, S. J. (1981). The steady state of deformation. J. Geotech. Engng Div. ASCE 107 No. 5, 553-562.

Poulos, S. J., Castro, G. \& France, J. W. (1985). Liquefaction evaluation procedure. J. Geotech. Engng ASCE 111, No. 6, $772-792$.

Sitharam, T. G., Dinesh, S. V. \& Shmizu, N. (2002). Micromechanical modeling of monotonic drained and undrained shear behaviour of granular media using three-dimensional DEM. Int. J. Numer. Anal. Methods Geomech. 26, No. 12, 1167-1189.

Sitharam, T. G., Dinesh, S. V. \& Srinivasa Murthy, B. R. (2003). Critical state behaviour of granular materials using three-dimensional discrete element modelling. In Granular materials: Fundamentals and Applications (eds S. J. Antony, W. Hoyle and Y. Ding), pp. 135-156. London: Royal Society of Chemistry.

Sitharam, T. G., Vinod, J. S. \& Rothenburg, L. (2005). Shear behavior of glass beads. Proceedings of the international conference on micromechanics of granular media, powder and grains, Stuttgart, pp. 257-260.

Tatsuoka, F. (1972). Shear tests in a triaxial apparatus: a fundamental study of the deformation of sand. $\mathrm{PhD}$ thesis, Tokyo University, Japan (in Japanese). 